\title{
Postmodernism, identity and mission continuity in the Church of Christ in Zimbabwe
}

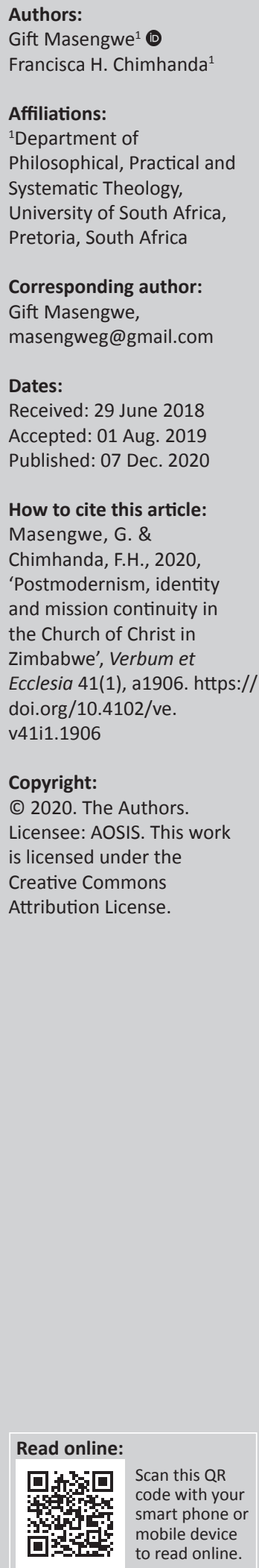

The Church of Christ in Zimbabwe (COCZ) is a Christian denomination with its own internal substance and purpose in life. However, postmodernist changes have affected the Church's operation with religious, ethical and spiritual implications. The COCZ engaged in conference centre construction (at Somabhula, Gweru South, Zimbabwe), constitution making (adopted 2014) and further ministerial formation through university education. The study was conducted among the Lukuluba people of Somabhula using qualitative research methods. Activities among the Lukuluba people need to be done in critical review of the church's ideological duty, discovery of the Lukuluba people's religious consciousness and development of a contextual pedagogy that appeals to the people's religious spirituality. The study found the need to review the modes of Lukuluba cultic practices of the Shona Mwari religion for purposes of attaining mission continuity within the community and being mindful of the need to continue in the founding identity of the COCZ.

Intradisciplinary and/or interdisciplinary implications: Identity and mission continuity of the Church of Christ in contemporary Zimbabwean society relates to human creation, baptismal dignity and vocation as systematic theology has ecclesiological, soteriological, incarnational, existential, ecological, biblical, inculturational and missiological implications.

Keywords: Church of Christ in Zimbabwe; Somabhula Conference Centre; Lukuluba Community; African cultural hermeneutics approach; Christian identity; Christian mission; postmodernism.

\section{Introduction}

This article examines engagements of the Church of Christ in Zimbabwe (COCZ) in light of religious, social, political and economic changes associated with postmodernism on the continuity of its Christian mission and identity. This empirical study was conducted with the aim of finding the contemporary view of the identity and mission of the COCZ. Understanding the COCZ's ideological duty as a Christian denomination and the underlying consciousness of the Lukuluba people who are serviced by the conference centre can be regarded as a first step towards successful mission and identity continuity. The conference centre project here plays a mediatory role between the church's transforming theological identity and its past missionary successes which included evangelism, education and health delivery (Reed 1972:39-41). Somabhula Conference Centre thus is a recap and recapture of the church's mission and identity in a broader milieu of Zimbabwe's transforming religious landscape, especially the ethical and moral struggles of political leaders. Somabhula Conference Centre is a significant context for this study because it is the first project of the COCZ conducted by indigenous people without external help from white missionaries and foreign funders. The project benchmark shows that all future responses by local Christians will be done. Somabhula Conference Centre helps appraise identity and mission continuity in the COCZ's engagement in evangelism and social development, and hence, this study proposes for the need to understand the geography, the history, the religious institutions and the methods to use for effective ministry, mission and service to the Lukuluba community. The research question was the following: what role is the COCZ playing at Somabhula Conference Centre, and how is it upholding its missional endeavour on the Lukuluba people in a postmodernist era? This is elaborated by the following questions: (1) what impact does the conference centre have on the Lukuluba community? (2) What role does the COCZ play in changing the religiosity and spirituality of the Lukuluba people? (3) In what way is the COCZ's response to postmodernism useful for Christian mission and identity among the Lukuluba people?

The context and location of Somabhula does not assume to address issues that cut across many Shona communities, but provides tentative assumptions for the surrounding communities of the 
conference centre. Thus, the study locates the church community in the 'perception and practice' (Russell 2011:2527) for effective 'modes of perception and practice' (Comaroff \& Comaroff 1986:2) in Christian mission and identity. Identity and mission continuity rests at the centre of the COCZ's postmodernist responses, wherein conference centre construction has been singled out for this reflection to allow the church to embark on its vision of being a missional church (COCZ Strategic Plan 2015-2019). The vision allows the COCZ to prophetically and religiously address the challenges of the Lukuluba community. For the success of any local projects there, the COCZ needs to be theologically prepared for its spiritual duty as well as understand the religious consciousness of the Lukuluba people. Being Church of Christ implies an incarnational presence of God in an everchanging community that continuously transforms and renews its theology to address human activities in dialogue with biblical norms. This moral intelligence hopes to go beyond the confines of the Lukuluba community.

\section{Methodology, study tools and data collection Theory for the study}

The study uses the African cultural hermeneutics approach (ACHA) developed by Musimbi Kanyoro to interpret and transform cultural tendencies of patriarchy in the church. This approach re-interprets church governance and theology in service to an African congregation, especially after many years of religious rivalry with the Christian coloniser. In The Rhodesia Herald (19 April 1895), Africans are referred to as (Guvamatanga 2014):

$[U]$ ntutored savages, accustomed $\ldots$ to superstitious and primitive ideas of law and justice, and [cannot be governed] by the same code of laws that govern a people with many centuries of experience and enlightenment. (n.p.)

This was earlier on stated in The Rhodesian Herald (07 January 1893) (Guvamatanga 2014):

One need not have the slightest hesitation in affirming that throwing open law courts the Mashona is a great folly as it would be to give his race honoured seats at our tables or office of authority. (n.p.)

African cultural hermeneutics approach gives us some form of 'analysis and interpretation of how culture conditions people's understanding of reality at a particular time and location' (Kanyoro 2002:9). This approach 'is the choice of combining an affirmation of culture and a critique of it that will have the potential to sustain the modern Africa' (Kanyoro 2001:57). Thus, Christian mission and identity takes on the new hermeneutical tools useful for introspecting the African culture and the Gospel in a postmodernist society.

\section{Study design}

The study targeted Christian men and women of Somabhula Conference Centre who resided in the Lukuluba community for 18 years and above. Somabhula Conference Centre was purposively chosen for the study because the centre is crucial for the mission and identity of the COCZ. The study used descriptive methods for data collection, which involved conversations and key informant discussions. Interviews took 'less-structured research strategies that avoid creating a difference between the interviewer and the interviewee' (Perii \& Bellamy 202:304; 244). Interviews such as key informant and in-depth interviews, as well as focus group discussions (FGDs), were utilised for collecting qualitative data.

\section{Sampling procedures}

The researchers have conducted sampling in two stages, which is also supported by De Vos (1998:189-200), namely (1) a group of members of the COCZ who attend services at Somabhula Conference Centre who are not originally from the Lukuluba community, especially teachers, nurses and agricultural extension workers; and (2) members of the Lukuluba community who are members of the Somabhula Conference Church who reside in the community. The inclusion and exclusion criteria where non-COCZ members are part of the study sample were envisaged to be helpful in the study as the activities of the COCZ are supposed to transform the Lukuluba community, and the contributions of prominent community leaders helped inform the COCZ on how to approach its activities in the community. The study aimed at assessing the impact of the COCZ in a postmodernist society. Also the non-COCZ participants are not necessarily traditionalist members, as most of them are members of other church denominations with useful views on how the Church can have an impact on the society in the future.

For the first group, three members who were resident at Somabhula Service Centre and who were not originally from Lukuluba community but happened to be resident because of work were purposively selected. Another three people originally from the community with influential posts in the community, such as the councillor, sub-chief and village development coordinator, and not necessarily members of the COCZ were further purposively chosen. For the focus group discussion, six participants from the church were chosen without considering their affiliation with the Lukuluba community. In total, 12 participants were chosen to represent a church membership of 60 people currently attending regular services at Somabhula Conference Centre. Twelve participants represent over $20 \%$ of the researchable population in the study.

\section{In-depth interviews}

Three in-depth interviewees, a female councillor and two male leaders, a sub-chief and a village development coordinator were purposively chosen and volunteered to participate in the in-depth interviews. Resident members of the Lukuluba community were chosen for in-depth interviews because of their ability to inform the researchers on the incarnation of the God of the Bible through their community experiences. They are familiar with the religious 
climate of the Lukuluba people, and at times are participants, hence were very useful for giving in-depth understanding of the incarnational presence of God in this community. Indepth interviews allowed the researcher to get an in-depth understanding of the religious consciousness of the Lukuluba people. However, in-depth interviews were over-reliant on a few individuals whose memories of the events were full of personal interpretations rather than facts.

\section{Key informant interviews}

Three key informants - two women: a former teacher and a retiring nurse; and one man, a former worker with the National Railways of Zimbabwe - were interviewed. Members of the COCZ were useful for the discussions as key informant interviewees as they could relate community stories with the work of the COCZ in the Lukuluba community. These interviewees were useful for contextualising the study for both the church and the community. Participants selected for this interview had been in the community for more than 40 years and some had retired and had bought houses at the Service Centre. Such interviewees could relate well with the experiences of the Lukuluba people without the biases of the community members. Key informants were selected from among professionals in these two fields and are people who had interacted with the community for a long time. Inductive studies mainly depended on extensive narratives of religious and cultural historiographies by longest serving members of the church at Somabhula Conference Centre in the Lukuluba community.

\section{Focus group discussions}

One focus group discussion consisting of 3 women (2 aged between 15-24 years and 1 aged between $25-39$ years); 3 men (age between 25-39 years) and an elderly man (aged between 40-60 years) who were members of the COCZ and who attended services regularly at Somabhula Conference Centre were chosen without regard of their longevity of stay in the community but had been members of the denomination for more than 5 years. Selection was based on availability and willingness to participate. Discussions brought forth perceptions of religious consciousness of the Lukuluba people. While some interviewees preferred English, FGDs were conducted in the vernacular and notes were taken in the process. The interview took over $1 \mathrm{~h}$ and $30 \mathrm{~min}$.

\section{Data management and analysis}

Note-taking was used to capture qualitative data in an exploratory empirical study (Babbie \& Mouton 2001:79). Data were transcribed, translated and typed using data analysis software for ethnographic material (Altheide 1987:65-77). Data looked at the history and experiences of the Lukuluba people over the years and their relationships with the spirit world. This enabled the researchers to establish themes to assist in data analysis and interpretation as presented in the discussion section of this article.

\section{Ethical consideration}

The study was carried out as part of the broader $\mathrm{PhD}$ study for the first researcher, and a permission letter was obtained from the national executive. Participants were not coerced to participate. They were informed of the permission that was obtained from the National Executive of the COCZ to carry out a study on 'The Church of Christ in Zimbabwe: Identity and Mission Continuity (in diversity)'. Participants did not receive any information that compelled them to participate without deception or inducement. Privacy, anonymity and confidentiality were promised and observed throughout the study. Consent was obtained verbally as the study was conducted during the August 2018 church conference, and the national president had highlighted that that 'Gift Masengwe is a PhD student who is carrying out a contemporary study on the COCZ's identity- and mission-continuity in this time of religious plurality' (SCC 2016). However, as required by research ethics, participants were fully informed of the purposes, objectives, participant expectations, voluntary participation, permission to withdraw at any moment and removal of all leading hints to one's identity. Also all participants had to be of a consenting age (18 years and above) and that no assent forms were going to be signed as children under the age of 18 were not required to participate.

Minimum ethical requirements were observed such as acknowledging other writers' works and asking or seeking consent from interviewees.

\section{Conceptual descriptions and contextual location of the study The Church of Christ in Zimbabwe}

The COCZ is a theologically, socially and politically or legally constituted missionary organisation (Sengers 2012:55). Firstly, it is a (Sengers 2012):

[G]roup of the faithful who, at the commandment of Jesus Christ, regularly assemble to study the Scriptures, to celebrate the Sacraments [especially the Lord's Supper], and to preserve the Apostolic tradition (Ac 2:42). (p. 55)

This Christian religious organisation also has a message and vision for all people in society. Lastly, it is guided by a constitution and registered as a non-profit-making organisation with political space and legal protection to operate within the geographical space of Zimbabwe. In fact, it is an institution that is governed by a 'national church constitution, new structures and changes to the old model of autonomy increased accountability by vesting power in the highest decision making body, the National Conference Council (NCC)' (Masengwe \& Chimhanda 2019:2). This ensures that it fulfils its historical and theological mandates, remains relevant and is legally and politically bound by the laws of Zimbabwe. Its internal identity is aligned with the Protestant Reformation, but in no way homogeneous, and has had its own controversies and ambiguities over the years; hence, it vacillates between conservatism and liberalism 
(Manyonganise 2016:21). Phenotypically, it is classified as ecumenical, with emphasis on unity and fellowship that it never achieved. In all, its faithfulness to identity and mission is marked by movement and changes on Christian education, hospitality, community service, worship, contemplation, discernment, justice and diversity (Bass 2006), with recognition of Jesus Christ as the ultimate head of the denomination.

\section{Christian identity and Christian mission}

The COCZ has been challenged by the changing religious landscape of Pentecostalism and its impact on the Zimbabwean society. The churches that have impacted Zimbabwe, as Kottak and Kottak (2013:429) concur, have identities of their own associated with what they have and own, their systems of leadership and their leaders, articulation of their theologies and histories, growing numbers of members, and dynamic methods of membership acquisition, unifying centres of operation, centralised power and others. Christian identity thus relates to how Christians of a particular denomination act in relationship to Christians of another denomination. In a way, this study accepts the plurality of Christian identities and the moving nature of the way they are perceived. In this context, this article streamlines the notion of identity in line with the mission of the COCZ. Historically (Barth 1932):

[M]ission has been in the old church a concept of the action of the Trinity, i.e., a reference to the divine self-sending, the sending of the Son, and of the Holy Spirit into the world. (p. 88)

To bring Jesus to the Lukuluba people, mission discourse needs to explore (Johnson 1992):

[A] theology [of] God starting from below, beginning with the vivifying and renewing of the Spirit as God's presence in the World and exploring in succession speech about each of the 'persons' of God's Trinity. (p. 13)

The Trinity is understood in singular and multiple terms at both one and multiple images of God at the same time. Trinity is 'the expression of the Mystery, both one and multiple, that envelops us, that has made us what we are, and in which we participate ceaselessly' (Gebara 1999:153, 1996). The act of God reaching out to us by the Holy Spirit is described by Stephen B. Bevans as 'God inside out'. He states, 'God's deepest nature ... is discerned by focusing, not on God's inner Trinitarian, communal life but on God's "eccentric", "centrifugal" reaching out to the world in love' (Bevans 1998:102). In this way, the COCZ is being called to be the 'church inside out' if it can become a part of God's mission and not the COCZ in its own temporal mission. In God's mission to the world, it should take 'an embrace made flesh in Jesus but accomplished already in the past, present, and continuing presence of the Holy Spirit' (Bevans 1998:103).

\section{Postmodernist Zimbabwean society}

The political, economic and social changes that characterised Zimbabwe between 1990 and 2010, the lack of moral intelligence among national leaders, lack of internal national capability to deal with changes in the global society and backward planning all led to retrogressive operations in Zimbabwe. The economic failures, political impasses, social declines and religious pluralities (Muzondidya 2007:325341) that characterised the country like the Fast Track Land Reform of 2001-2003 (Matondi 2012); the Operation Restore Order of 2005 (Bratton \& Masunungure 2006:21-45; Musoni 2010:301-317; Potts 2006:273-291; Vambe 2008); and the hyperinflationary environment of 2007 (Hanke 2009; Hanke \& Kwok 2009:353) that connected to the 2008 presidential rerun violence and associated health, food and education problems (Hammar 2008:417-434; Mlambo \& Raftopoulos 2010) were responses to challenges posed by postmodernism, and this has led to political compromises such as the 2008 infamous signing of the Global Political Agreement (GPA), to form the Government of National Unity (GNU) in a 'marriage of convenience' 'masked with uncertainty' (Sibanda \& Masaka 2010:250). Postmodernism has brought challenges that have transformed how religion, economics, politics and communities are structured, hence the challenge of postmodernism to the church's identity and mission continuity.

\section{Results: Determinants of Christian identity and mission in the Lukuluba community Socio-demographic variables of participants}

The six interviewees were systematically analysed in view of the results of the focus group discussions as outlined in the sampling procedures. Participants who took part in the study were not all from the COCZ as one was a member of the Seventh Day Adventist, one was a traditionalist and the other was from the apostolic sects. The study found that 5 of the 12 participants were not professionally trained and that of the 7 professionals, 3 were women. In all, 8 of the 12 participants were sure of their salvation, while 4 were unwilling to reveal their stand on the idea of Christian salvation. In total, six men and six women participated in the study.

\section{Acquiring Somabhula Conference Centre}

Interviewees and focus group discussions stated that the COCZ took advantage of the government land redistribution programme among the landless poor black majority codenamed the Fast Track Land Reform Programme (FTLRP) of 2001-2003 to acquire Somabhula Conference Centre for the purposes of building a boarding school and to erect the church's first conference centre, both sponsored by indigenous people. Somabhula Conference Centre came up as a result of a congregation that was started by four women and one man: Mrs R. Mafuta, Mrs J. Maramba, Mrs L. Gwenzi, Mrs M.B. Sibane-Nyoni and Mr S. Mdedeli. Tradition subsists that Dadaya Mission used to send evangelists to Dorset, such as Revd. J.N. Hlambelo and Mr Ray Knapp. In the current arrangement, Gweru urban, which is $37 \mathrm{~km}$ from the town, 
has been sending preachers, notably Pastors O. Zidya, A.P. Chinyoka, G. Mangunda, O. Banda and Revd. N.M. Sithole. All interviewees stated that Revd. N.M. Sithole played a key role in acquiring papers for the conference centre. Members of the church worked at the conference centre with urgency, inspired by God to serve the community.

\section{Situating the conference centre among the Lukuluba people}

Somabhula Conference Centre is situated in King Lukuluba's community, under Gweru South District. King Lukuluba ruled all the land between Ghogo Mountain, Hwaya Mountain and the plains, now known as Somabhula. One of the key informant interviewees, who is the oldest member of the church and has stayed in the area for more than 40 years, said 'Lukuluba' is probably a Ndebele version of the Shona 'Rukuruva' which may have meant 'dust'. The name may have been derived from the type of soils in the area that are dusty or from the people's love for farming. It however cannot be denied that the term is associated with what Field and Masengwe (2002) call being 'the son of the soil'. Lukuluba thus was of Rozvi dynasty, and history says that they lived close to the Ghogo Mountains where they also worshipped Mwari religion through traditional rituals. Ghogo Mountains were called 'intaba zikamambo', in Ndebele, for the King's Mountains, meaning where the king resided, ruled and worshipped Mwari.

\section{Relating the historical episodes of the Lukuluba people}

The Lukuluba kingdom was threatened by Ndebele raids of King Lobengula before whites came. King Lukuluba is said to have sent 10 girls to make peace with King Lobengula, who in turn kept his cattle from Mashonaland at Ghogo Mountains. However Lobengula did not trust King Lukuluba, so he sent Jahana (probably Christian, John) to settle at Nsindane (now DeBeers Range/Deb-Shan) as Ndebele chief to oversee Lukuluba. Interviewees argued that the history of the Lukuluba people was distorted by colonisers.

The key informant interviewees agreed that the last Lukuluba king, 'King Shumba', was arrested between 1945 and 1948 and was taken as a prisoner to Zhombe in handcuffs during the Land Apportionment Act. The later whereabouts of his headman, Mudzingwa 'Shoko' (of the monkey totem), are not known, as no one has information of what became of him. 'Shumba' (of the lion totem) has striking resemblances with Jesus Christ, the Lion of the tribe of Judah.

Key informant interviewees further stated that the king was asked to pay 10 pounds because he asked the governor:

Munondipireiko nyika inopakurirwa mombe chikafu savanhu? [Why allocate to me a dry land where animals are watered by buckets like human beings?].

People were resultantly spread and dispersed into various places in the country including Gokwe, Zhombe, Mazetese
(Sarauru) in Mwenezi. One in-depth interviewee resident of the area argued that:

Colonial dispersal weakened our people from waging an uprising. All their properties such as cattle, sheep and goats were confiscated. People became very poor as drier areas they were allocated did not support adequate crop and animal production.

At the end of independence, whites continued to occupy the Lukuluba area until the onset of the FTLRP of 2001-2003. One of the most informed of the six interviewees, supported by focus group discussants stated:

Since then [land reform], Ghogo Mountain is no longer regarded as sacred for African communities resettled there, and the ZANU Party youths who camped at Topota fetched water from the pool with modern metal buckets previously put on fire. Also girls washed 'panties' and 'braes' in the pool.

\section{Appraising religious and cultural practices of the Lukuluba people}

The people of Lukuluba worshipped at a place called Topota (maybe Shona, kupotera - 'appealing') near a natural, perennial water pool between the rocks. The water is believed to have been used for clean community drinking water and for traditional ritual purposes. One of the in-depth interviewees stated that:

Dziva iri rinofungidzirwa kuti raishandiswa kuchera moura yokuitisa mutoro wokunayisa moura. [The pool is believed to have been used for fetching water to brew ritual beer (mutoro also mukwerera in Shona)].

Traditional ritual practices are believed to be associated with the worship of Mwari at Matonjeni and Njelele shrines in Matopo District, Matabeleland South, on the southern part of Bulawayo Metropolitan province.

Another male participant from the key informant interviewees revealed that:

Padziva apa paimera mhodzi yaibereka mikombe mitatu pagore roga roga. Hapana anoziva kuti mhodzi iyi yakaiswa nani uye yairamba ichimera sei, asi vakuru vaizotora mukombe umwe chete wakanaka wokushandisa kuti mamwise mutoro nawo. Vapedzazvo vaizopwanya mukombe uya nechirongo chavanenge washandisa, kuti moura ibve yanaya. Zvinonzi pavingopedza kudaro, vanhu vaizosvika kumba vaakutonayiwa nemoura, voti Mwari atinzwa. [At the pool grew a plant that produced three pods (mhodzi) only every year. No one knows who threw the seed of the plant there and why it continued to grow and produce only three pods, although the traditionalists took the best of the three to use in fetching beer from the beer pot. After that they would break away the 'chirongo' (water carrying pot), 'mukombe' (beer fetching tool) and 'chipfuko' (ritual beer pot) to mark the coming of the rain. After the ceremony, they usually arrived home in the rains, saying 'God has head us' (translation)].

Furthermore, focus group discussions indicated that:

Mudziva rakarero, maiva nehove dzaionekwa dzichishambira asi dzisabatika, dzaiti ukakanda chiredzo nobwazvo, dzaisadyira. [In the pool, fish were seen but no one could catch them because they did not eat the bait on the hook (translation)]. 
Both key informant and in-depth interviewees confirmed that:

[D]iscrete fish were reportedly seen in the pool; which is between rocks and there is no source of food, although green plants are said to have been growing close to the pool.

The traditionalist further revealed that 'people here lived on bananas that grew by the pool, even though there is no clarity on the origins of the plants'.

Key informant and in-depth interviewees agreed that people lived closely to the pool that they kept large grain storage belly pot (makate) for community surplus grain - grain bank. Surplus grain was used during droughts and famines.

A key informant interviewee who has stayed in the area for so many years further stated that there were also smaller belly pots (makate) that had:

Nyuchi dzakawanda dzaive nouchi hwakabatana, hwaizoburwa hwopiwa kuvanhu kuti vadye. [Many bees swarming in and out; and had heavy honey which would be harvested to give as food to the people (translation)]

On food, one interviewee from in-depth interviews stated that the King's Mountains had monkey berries (mashuku), which were received with clapping (as respect to the gods). Interviewees agreed that mischief in the holy mountains led to punishment such as disappearance or death. These stories are associated with taboos and curses for not obeying spirit beings.

Finally, the respondents stated that:

At the pool, grew three 'mbanje' [marijuana] branches that were smoked for ritual processes by elderly traditional mediums only during rain-making ceremonies at the top of Ghogo Mountain. If rains did not come after the rituals, the king summoned people to send three different emissaries to Matonjeni to inquire of reasons for rain failure. Messengers were sent on different routes, and at different times, and reported their findings differently. If their messages differed, three new emissaries were sent until they all brought the same message.

In all, the idea of three has deep theological and spiritual meaning to the Christian church, and has significance for the Jewish and Christian God. Three is a significant figure for truthfulness and credibility of witnesses in the Old Testament as well as the completeness of the Godhead in the New Testament.

\section{Discussion}

The study focused on determinants of Christian identity and mission through a study of the Lukuluba community. Members of the COCZ understand their receipt of Somabhula as the working of God to create for them a platform for ministry and service to the community. This work needs to begin from the conference centre in accordance with Christ's formula (Ac 1:8), as members of the COCZ are inspired to effectively evangelise the Lukuluba community.

\section{Understanding Lukuluba ontology and epistemology}

The Lukuluba people are of Moyo totem from the Rozvi and Monomutapa kingdoms. They speak Karanga, one of the six Shona dialects spoken by more than $80 \%$ of the Zimbabwean population. The Shona regard land as sacred, attach themselves to a dunhu [fixed region], have a chidao [clan poem] and observe chisi [traditional rest days]. In fact, Bourdillon (1987:67) says they 'see more in their land than simply usable property ... intimately associated with the history of the chiefdom'. Land influences their economy, politics and spirituality, and the vast universe has an origin and owner (Mbiti 1991:45). Of significance in this matrix are God's trustees, the elders, mediums and ancestors. God kept a personal relationship with all people, to drive the bandwagon of final consummation (Masengwe 2011:39). God who originated and cared for all things among the Shona was conveyed in figurative language and poetic imagery (Mbiti 1992:49). God was approached at Matonjeni through rituals to fulfil this attitude where the Venda priests mediated in the complex Mwari rain-making system. Venda priests were believed to receive sacred messages from the High God. The High God was brought to the people by rituals at the cultic centre (Bhebhe 1979:96). Ancestors were seen in the rituals as a central feature of their worship because they organised and maintained creation, leading to their dominance in the religio-traditional spiritual reality (Bhebhe 1979:94). Priests received and communicated God's messages to the people who in turn offered requests, especially through corporate rituals to avert punishments such as droughts, famines and wars. From this background, the conference centre strategy is to find networks in the Lukuluba community for the worship centre is a comparative place to the ritual centre at Ghogo Mountains. Worship centres should be turned into places of social development as rain-making was more of a social development issue rather than a worship issue. Development programmes create long-term relationships in resettled agrarian communities (Oliver \& Atmore 1994:146).

\section{Guaranteeing belonging to the Lukuluba people}

Land reform resembles Israelite covenant history with Yahweh, where Lukuluba people have a perpetual tenure of their land (May \& Williams 1997:41). Resettled communities have agrarian needs, such as rains, fertility and freedom from pests. Besides blessing the farming enterprise, there is a need for sustainable structures, such as farming clubs and expertise. This allows them to enjoy the fruit of their labour through 'presupposed normal work of agriculture' (Wright 1983:78). Like Israel, blessings abound in the 'pursuit of historical belonging that includes a sense of destiny derived from such belonging' (Brueggemann 1977:3). The COCZ can guarantee belonging to the Lukuluba people 'based on the gift of their own land in the historical outworking of God's redemption and on God's covenant of love' (Wright 1983:75). They need to know that they are (Brueggemann 1977):

$[T]$ o be in a place, perhaps for an extended time, to live there and take some roots, but always to be an outsider, never 
belonging, always without rights, title, or voice in decisions that matter. (p. 7)

Somabhula has a mission, both in temporal and spiritual needs of the people, as they live on that land (Wright 1983:77). Ritual and ceremonial practices are markers of the settlement as land is 'shared and passed on to future generations' (May 1997:90). Somabhula's mission is to help Lukuluba observe 'the weightier matters of the law' (Mt 23:23; May 1977:85-86). The process demands dialogue between the community and the church in reinterpreting both Christian and Lukuluba customs and traditions (Iliffe 1995:226). In locating the church among the Lukuluba people, the church must be willing to revisit its own identities in light of traditional rituals. This can be enhanced through pastoral engagements of the traditional leadership, and the creation of a platform for conversation and dialogue.

\section{Theophany and theosophy among the Lukuluba people}

The idea that at Ghogo Mountains the shrine of the Mwari Cult had striking significances with the biblical images of the Godhead produces a number of explanations. Firstly, the idea that the creeper produced only three fruits, the 'mbanje' also had three branches and the King would send three emissaries could be a reflection of the transcendental nature of God upon all peoples of the earth. However, some contend that the Shona culture could have possibly been contaminated by the Jewish or Islamic traders who probably taught that three was a figure for completeness. Some also feel that probably Father Gonzalo Da Silveira had taught about one God in three substances. In all, there are striking resemblances between the Mwari cult and the biblical examples of the trinity; and this may require serious reflection on the community and their belief of the Mwari cult. Similarly, the breaking away of the used utensils in the ritual process has striking resemblances with passing on of the past season and the incoming of a new season in the life of the community. Interviewees however indicated that Topota was no longer effective as the mythical and mystical stories can no longer exist. The conference centre rather can be viewed as a new Topota for the Lukuluba people if the COCZ seriously considers its essential body-politic for religious and spiritual transformation. Identity and mission continuity can be reflected in the words, 'Mwari atinzwa' [God has heard our cry], to those who are going to be transformed through the fullness of God the Father, Jesus Christ the Son and by the renewal of the Holy Spirit. This study has observed that respondents emphasised the subject of Trinity through striking resemblances in the Mwari cult. Trinity is important to us because of Jesus Christ, the central to human salvation in Christianity, 'our elder brother in Adam' (Nyamiti 1984:17). Christ goes beyond ancestors as he bridges the gap between humanity and God (Bediako 1979:101). 'Such relationship is, therefore, essentially connected with our grace of adoption, and thereby entails practical consequences which are more demanding and, hence, more salutary for us' (Nyamiti 1984:17). Christ died and rose from death, giving him far-reaching qualifications to better perform duties claimed by traditional textuaries, as he pre-exists and post-exists all of creation (Masengwe 2011:54). This means the exalted and glorified Christ supersedes ethnic ancestries and has full knowledge of the world. Christ therefore can represent the Lukuluba people before God in a better way compared to their patriarchs and ancestors. The COCZ needs to present Christ in Somabhula to permeate and replace tribal ancestries as Christ takes tribal roles of ancestors.

Furthermore, imageries are a symbolic language, which is a theosophy that raises interesting questions on revelation or theophany. Lukuluba traditions have much similarity with the Jewish and Christian traditions and are expressive of the relationship of God and humankind through ritual practices. The biblical sacrifice of Jesus Christ and the material expression of his incarnation are found through nature in every community. Masengwe (2011:56) argues that Christ through the Holy Spirit is at the centre of every community and people use the gifts of nature to express this relationship. Field and Masengwe (2002:73-79) argue that the 'living' and the 'living-dead' are in communion through an expressively deep spirituality from nature. Somabhula thus engages the COCZ's quest for identity continuity in the context of new mission among the Lukuluba communities. Thus, education, health and evangelism become intertwined in its approach to cultural transformation among the people (Hastings 1967:119; Reed 1972:39-41). The church is doing not only evangelisation but also humanisation and civilisation among the African populace. Christian identity and Christian enterprise call for an in-depth review and interaction of the Lukuluba traditional beliefs and practices in view of the biblical enterprise of the postcolonial era in order to serve members of the community (Ubah 1988:82).

\section{The anthropocosmic reality and gender issues}

Rituals express implicit God-human-creation relationships. Ancestors are regarded as senior citizens of the community who communicate with the gods in the fullness of life (Magesa 1998:178). In the same way, Lukuluba people respect ancestral graves as providing native paths for bonding past and future generations with a specific geographical locale. The Lukuluba community thus honours invisible realities of ancestors as authentic spiritual identity 'in elaborate Mwari ceremonies' (Daneel 1998:249, 254), for ancestors are 'shades' that closely bond 'kinship' relationships with lineage members in interdependent ways (Berglund 1976:197). Ancestors carry memories 'not only of [their] people, but also of all people; and not only of all people; but of all creatures' (Daneel 1998:254). This connects closely with totemic rituals which forbade in-breeding and cannibalism (Masengwe 2011:42). Rituals were done to God, and Bhebhe (1979), describing rain as a sacred product from God, states:

Lunji kusi fume ngubo belera fuma pasi [Needle which does not sew a blanket, it stitches the earth - raindrops pierce the earth which then sprouts]. Gumbo tandawara ibe muvumbi [His stretched out leg becomes drizzle]. (pp. 77-78) 
This description erroneously presents a male God, yet the Shona did not use pronouns to differentiate gender. A male Mwari seems to be a product of an assimilation of the Christian God into the traditional cultic system. Gender marginalisation needs redress to facilitate female headship to take titles for family properties. Racism and gender inequality have been blamed on the totalising attitude of Christianity in its humanisation and civilisation projects (Comaroff \& Comaroff 1991:2). The 'history of Israelite confrontation with the female element in Canaanite fertility cults' (McDonagh 1994:114) should be understood in terms of African authentic connections with life. God was not taught as one who knows no gender nor race, but rather as one who cares with a motherly heart and has protective fatherly arms (Is 52:12, 61:10; Masengwe 2011:53). This religious transformation differs from the colonial modernising project that emphasised evolution to dehumanise Africans for European exploitation (Green 2003:2). Christianity has been blamed in many places for taking away the sustenance people received from God through the sacred places (Masengwe 2011:40).

In Lukuluba community, for instance, as one of the key informants indicated, some Christians practise syncretism as they secretly participate in traditional rituals like mutoro ceremonies. Engagement with the Mwari cultic system in this community helps the church to fulfil its priestly function to address issues of crop failure and drought. If the church chooses a former colonial attitude, the people have their problem-solving structures and strategies through community leaders, spirit mediums, diviners and herbalists. Colonial cultures failed to eradicate traditional cultic practices (Kapenzi 1979). To minister to the people is facilitated by understanding the worship of Mwari. The very burial of Cecil J. Rhodes at Matonjecni was in anticipation of the priestly, prophetic and kingly role acquired for the worship of Mwari. Colonialists further enacted the 1899 Witchcraft Suppression Act (Banda \& Masengwe 2018) to forestall the God-human-nature relationship among the people. The COCZ thus can do itself a favour by interrogating chiefs and headmen on spirit-human-land relationships. The church can connect with power-holders by answering the question, how did people receive food from God, and how is the church continuing with that mission?

\section{Incarnating the Gospel of Christ in the Lukuluba identities}

The idea of Trinity in the Lukuluba community presents an opportunity to teach about the incarnation of Christ. Christ is the perfect communication of God to creation (Col 1:15-18; Osborn 1993:109). By incarnation, 'the glory and the character of the triune God' (Field 1999:49) permeates Christian and African worldviews. Setting foot into the Lukuluba community incarnates Christ among local populations, without threatening people's identities. The Shona ancestors were embedded into an elaborate system of agrarian cycles (Daneel 1999:116) that need to be revisited to redress colonial condemnation of the African cultures and traditions that hindered the preaching of the Gospel among local populations. Higher levels of cultural sensitivity can uphold good traditional beliefs and rituals that in turn can incarnate the Gospel in time and space (Kirby 1994:60-61). As one key informant interviewee retorted, ritual beliefs form the identity of the people, and thus, 'while people want to be converted from their flawed religious belief systems into Christianity, they do not want their identities to be destroyed first before conversion'. Like Chitando (2010) observed, traditional communities are saying to the church:

[I]f you want us to become Christians, allow us to be different Christians from Europeans, for Christianity must embrace African identity, African heritage and African personalities in terms of theology, institutions and geographic identities. (p. 116)

Finally, incarnating the Gospel requires the use of orthopraxis rather than exclusive orthodoxy. Christ should be understood as the God of the cosmos, the incarnate redeemer of the world in view of missionary negation of Africa as hopeless (Magesa 1997:20), against western burglary on African people (Hastings 1967:60). This challenges the church on veneration and valuation of African ancestors (Boulaga 1984:22). In primal communities, ancestors are important for the provision of existential needs, a function the cosmic Christ should successfully take over and perform beyond measure. This function should be understood in the context of the Holy Spirit for 'God loves and desires the welfare of the whole person' (Anderson 1992:63). Daneel (1999) argues that:

It is always the Spirit who brings the activity of the Son to its goal. Everything that exists does so through the inflow of the cosmic Spirit's energy and potency. (p. 107)

The Bible in John 6:63 says, '[ $t]$ he Spirit gives life, the flesh counts for nothing. The words I have spoken to you are Spirit and are life'. With Christ as a paschal mystery, the community's rituals are replaced and the presence of the Holy Spirit overtakes all the functions and problems of mhepo [evil spirits] in the family, as the Great Spirit from the Triune God animates and protects the community from lifethreatening forces of mhepo. The Shona people believe that certain powers reside in certain plants and thus wear amulets, anklets, wristbands, waistbands and necklaces to protect them from evil spirits (Masengwe 2011):

Traditional healers are called to peg out homesteads and fields [to protect] them from evil forces with prophetically blessed stakes. The good spirits are invoked to help order human life. In this way, the Holy Spirit comes in to influence [as the Great Spirit among the good spirits]. (p. 55)

The COCZ identity and mission continuity thus hinges upon these elements, and how the Gospel is communicated to eradicate salvation and transformation of human communities.

\section{Conclusion}

The conference centre attempts to transform both the COCZ's internal and external forms of visible and invisible roles it plays (Ziramba 2004:xi, 8-11). It is not only an education 
centre but also a sacramental centre for the worship life of the church. This answers to the theological and divine mandate of going out into the entire world (Mt 29:18-20; Ac 1:8) to spread the Gospel and hence to expand the church's identity and mission into the entire world. This involves faith engineering as new practices are adopted in education and religion alike.

\section{Acknowledgements}

The Church of Christ in Zimbabwe's National Executive Committee, the Church Council and the respondents are duly acknowledged.

\section{Competing interests}

No monetary or personal gains have motivated the writing and submitting of this article except the academic purposes.

\section{Authors' contributions}

Both authors collected data and reviewed the literature. G.M. wrote the initial draft and F.H.C. reviewed and approved it.

\section{Funding information}

The article was not sponsored or funded by any organisation or agency.

\section{Data availability statement}

Data sharing is not applicable to this article as no new data were created or analysed in this study.

\section{Disclaimer}

The views and opinions expressed in this article are those of the authors and do not necessarily reflect the official policy or position of any affiliated agency of the authors.

\section{References}

Altheide, D.L., 1987, 'Reflections: Ethnographic content analysis', Qualitative Sociology 10(1), 65-77.

Anderson, A., 1992, Moya: The holy spirit in an African context, UNISA, Pretoria.

Babbie, E. \& Mouton, J., 2001, The practice of social research, Oxford University Press, Oxford.

Banda, C. \& Masengwe, G., 2018, 'Overcoming fear? A search for an empowering theological response to the fear of witchcraft among urban Zimbabwean Christians', Verbum et Ecclesia, 39(1), 1-10. https://doi.org/10.4102/ve.v39i1.1837

Barth, K., 1932, 'Die Theologie und die Mission in der Gegenwart', in Theologische Fragen und Antworten 5:3 (Zollikon, Switzerland: Evangelischer Verlag, 1957) pp. 100-126, quoted in Letty M. Russell, 1993, Church in the Round: Feminist interpretation of the church, Westminster John Knox, Louisville, KY.

Bass, D.B., 2006, Christianity for the rest of us: How the neighbourhood church is transforming the faith, Harper One, New York.

Bediako, K., 1983, 'Biblical Christologies in the context of African traditional religion', in V. Samuel \& C. Sugden (eds.), Sharing Jesus in the two thirds world, pp. 81-121, WB Eerdmans, Grand Rapids, MI.

Berglund, A., 1976, Zulu-thought patterns and symbolism, David Philip Publishers, Cape Town.

Bevans, S.B., 1998, 'God inside out: Toward a missionary theology of the holy spirit', International Bulletin of Missionary Research 22(3), 102-109. https://doi. org/10.1177/239693939802200302

Bhebhe, N., 1979, Christianity and traditional religion in western Zimbabwe, 18591923, Longman, London.
Boulaga, E., 1984, Christianity without fetishes: An African critique and recapture of Christianity, Orbis Books, Maryknoll, NY.

Bourdillon, M., 1987, The Shona peoples: An ethnography of the contemporary Shona, with special reference to their religion, Revised edn., Mambo Press, Gweru.

Bratton, M. \& Masunungure, E., 2006, 'Popular reactions to state repression: Operation Murambatsvina in Zimbabwe', African Affairs 106(422), 21-45. https:// doi.org/10.1093/afraf/adl024

Brueggemann, W., 1977, The land: Place as gift, promise and challenge in biblical faith, Fortress Press, Philadelphia, PA.

Chitando, E., 2010, 'African Jews: Expressing contested identities in tight spaces', in L. Togarasei \& E. Chitando (eds.), Faith in the city: The role and place of religion in Harare, pp. 107-135, Swedish Science Press, Uppsala.

Comaroff, J. \& Comaroff, J., 1986, 'Christianity and colonialism in South Africa', American Ethnologist, 13(1), 1-22.

Comaroff, J. \& Comaroff, J., 1991, Of revelation and revolution: Christianity, colonialism and consciousness in South Africa, vol. 1, Chicago University Press, Chicago, IL.

Daneel, M.L., 1998, African earthkeepers. Vol. 1: Interfaith mission in Earth-Care, University of South Africa, Pretoria.

Daneel, M.L., 1999, African earth-keepers: Environmental mission and liberation in Christian perspective, vol. 2, UNISA, Pretoria.

De Vos, A.S. (ed.), 1998, Research at grassroots: A primer for the caring profession, Van Schaik, Pretoria.

Field, D.N., 1999, 'Ecology, modernity and the new South Africa', Journal of African Thought 2(1), 45-53.

Field, D.N. \& Masengwe, G., April/August 2002, 'Alienated children of the soil: The challenge of the land crisis in Zimbabwe to Christian eco-theologies', Bulletin for Contextual Theology in Africa and Southern Africa 1 \& 2, 68-76.

Gebara, I., 1996, 'The Trinity and human experience: An ecofeminist approach', in R.R. Ruether (ed.), Women healing Earth: Third world women on ecology, feminism, and religion, pp. 13-23, Orbis, Maryknoll, NY.

Gebara, I., 1999, Longing for running water: Ecofeminism and liberation, Fortress, Minneapolis, MN.

Green, M., 2003, Priests, witches and power: Popular Christianity after mission in Southern Tanzania, Cambridge University Press, Cambridge.

Guvamatanga, G., 2014, 'Sobering reality check for Tsvangirai', The Patriot, viewed 21 July 2019, from https://www.thepatriot.co.zw/old_posts/sobering-realitycheck-for-tsvangirai/.

Hammar, A., 2008, 'In the name of sovereignty: Displacement and state making in post-independence Zimbabwe', Journal of Contemporary African Studies 26(4), 417-434. https://doi.org/10.1080/02589000802481999

Hanke, S.H., 2009, RIP Zimbabwe dollar, viewed 02 June 2019, from https://www. cato.org/zimbabwe?guid=on.

Hanke, S.H. \& Kwok, A.K., 2009, 'On the measurement of Zimbabwe's hyperinflation', Cato Journal 29(2), 353ff.

Hastings, A., 1967, Church and mission in modern Africa, Burns and Oates, London.

Iliffe, J., 1995, Africans: The history of a continent, Cambridge University Press, Cambridge.

Johnson, E., 1992, She who is: The mystery of God in feminist theological discourse, Crossroad, New York.

Kanyoro, M.R.A., 2001, 'Cultural hermeneutics: An African contribution', in M.W. Dube, (ed.), Other ways of reading: African women and the Bible, pp. 101-113, Society of Biblical Literature, Atlanta, GA.

Kanyoro, M.R.A., 2002, Introducing feminist cultural hermeneutics: An African perspective, Pilgrim, Cleveland, $\mathrm{OH}$.

Kapenzi, G.Z., 1979, The clash of cultures: Christian missionaries and the Shona of Rhodesia, University Press of America, Washington, DC.

Kirby, J.P., 1994, 'Cultural change and religious conversion in West Africa', in T.D. Blakeley, W.E.A. van Beek \& D.L. Thompson (eds.), Religion in Africa: Experience and expression, pp. 51-71, James Currey, London.

Kottak, C.P. \& Kottak, C.P., 2013, Mirror for humanity: A concise introduction to cultural anthropology, McGraw-Hill Humanities/Social Sciences/Languages, New York.

Magesa, L., 1997, African Religion: The Moral Traditions of Abundant Life, Orbis, New York.

Magesa, L., 1998, African religion: The moral traditions of abundant life, Paulines Production Africa, Nairobi.

Manyonganise, M., 2016, The Church, national healing and reconciliation in Zimbabwe: A womanist perspective on Churches in Manicaland (CiM), PhD thesis, University of Pretoria, Pretoria, South Africa.

Masengwe, G. \& Chimhanda, F.H., 2019, 'Towards an authentic transformation of the church of Christ in Zimbabwe', HTS Theologie Studies/Theological Studies 75(1), a4776, 1-11. https://doi.org/10.4102/hts.v75i1.4776

Masengwe, G., 2011, Land reform and the theology of development: The Zimbabwean fast track land reform (FTLR) program and environmental ethics, Lambert Academic Publishers, Bramberg. ISBN: 978-3-8443-2418-1

Matondi, P.B., 2012, Zimbabwe's fast track land reform, Zed Books Ltd, Harare.

May, R.H. \& Williams, A.V., 1997, Joshua and the Promised Land, General Board of Global Ministries, United Methodist Church. 
Mbiti, J.S., 1991,Introduction to African religion, 2nd edn. - Revised, Heinemann.

Mbiti, J.S., 1992, African religions and philosophy, 2nd edn., Heinemann.

McDonagh, S., 1994, Passion for the earth: The Christian vocation to promote justice, peace and the integrity of creation, Orbis Books, Maryknoll, NY.

Mlambo, A. \& Raftopoulos, B., 2010, 'The regional dimensions of Zimbabwe's multi-layered crisis: An analysis', in Election processes, liberation movement and democratic change in Africa conference, pp. 1-13. CMI and IESE, Maputo, viewed 22 June 2019, from http://www.iese.ac.mz/lib/publication/proelit/Luis_ Brito.pdf.

Musoni, F., 2010, 'Operation Murambatsvina and the politics of street vendors in Zimbabwe', Journal of Southern African Studies 36(2), 301-317. https://doi.org/ 10.1080/03057070.2010.485786

Muzondidya, J., 2007, 'Jambanja: Ideological ambiguities in the politics of land and resource ownership in Zimbabwe', Journal of Southern African Studies 33(2), 325-341. https://doi.org/10.1080/03057070701292616

Nyamiti, C., 1984, Christ as our ancestor: Christology from an African perspective, Mambo Press, Gweru.

Oliver, R. \& Atmore, A., 1994, Africa since 1800, Cambridge University Press, Cambridge.

Osborn, L., 1993, Guardians of creation: Nature in theology and the Christian life, APOLLOS, Leicester.
Perri 6 \& Bellamy, C., 2012, Principles of Methodology: Research design in social sciences, Sage Publications, Thousand Oaks.

Potts, D., 2006, "'Restoring order"? Operation Murambatsvina and the urban crisis in Zimbabwe', Journal of Southern African Studies 32(2), 273-291. https://doi. org/10.1080/03057070600656200

Reed, D.J., 1972, To an African drum, Mission Service Press, Kempton.

Russel, C., 2011, Classical Japanese cinema revisited, Blloomsburg, United States.

SCC, 2016, Somabhula Conference Centre (SCC) Bulletin 1, SCC, Somabhula.

Sibanda, F. \& Masaka, D. 2010, Marriage of convenience: Theological and philosophical reflections on Zimbabwe's Government of National Unity (GNU), Unpublished.

Sengers, E., 2012, 'The concept of "Church" in sociology and global society: Genealogy of a word and transformation of the position', International Journal for the Study of the Christian Church 12(1), 55-70. https://doi.org/10.1080/1474225X.2011.598300

Ubah, C.N., 1988, 'Religious change among the Igbo during the colonial period', Journal of Religion in Africa 18(1), 76-82. https://doi.org/10.2307/1580837

Vambe, M.T. (ed.), 2008, Hidden dimensions of operation Murambatsvina, The African Books Collective, Harare.

Wright, C.J.H., 1983, Living as the people of God: The relevance of Old Testament ethics, Intervarsity Press, Leicester.

Ziramba, E., 2004, From a doubtful past to a hopeful future, CAMELS Publishers, Masvingo. 